\title{
Quarantine of UV-Shine Itself Instead of Quarantine Infectious Agents as a Physical Control Method is the only Ever-Known Effective Way for Stopping the Spreading Potential of 2019-nCoV in China and Later Possibly Disseminate to the Global
}

\author{
Yi Yu Lai ${ }^{\text {ab }}$ \\ ${ }^{a}$ Medical Center, B343, Medical Science Building, Tsinghua University, Beijing, 100084. PR China \\ ${ }^{\mathrm{b}}$ Innoen non-profit organization, Mississauga, L4Z 3E4, ON, Canada. yylai[at]innoen.org
}

\begin{abstract}
The International Committee on Taxonomy of Viruses has proposed the name SARS-CoV-2 for the coronavirus that was provisionally called 2019-nCoV. Labs around the world are increasingly trying various solutions for curing or stopping the spread of this ferocious virus. The immunological vaccine solution is quite challenging since the envelopes of the viruses have already included human ingredients that detached from hosts. Most importantly, there is no time left for various chemical and biological studies to find an effective drug or vaccine. To stop the spreading at once is the top global urgent priority issue. Under the present condition, the physical method of applying ultraviolet lights and requires humans on-site with their own UV protection is the only one and ever known cost-effective method that can effectively stop the uncontrollable contagious spreading.
\end{abstract}

Keywords:SARS-CoV-2, 2019-nCoV, Ultraviolet (UV), quarantine the UV, conventional quarantine, UV radiation box(wall)

\section{Introduction}

Ultraviolet (UV) is electromagnetic radiation with a wavelength from $10 \mathrm{~nm}$ to $400 \mathrm{~nm}$, shorter than that of visible light but longer than $\mathrm{X}$-rays. UV radiation is present in sunlight and constitutes about $10 \%$ of the total electromagnetic radiation outputs from the Sun. UV radiation from artificial devices with wavelengths from 240-280 nm usually used for air, water, transparent materials, and shallow surface decontamination \& sterilization (DNA absorption has a peak at $260 \mathrm{~nm}$ ). Commercially available low-pressure mercuryvapor lamps emit about $86 \%$ of their radiation at $254 \mathrm{~nm}$, with $265 \mathrm{~nm}$ as the peak germicidal effectiveness curve. This one and diverse alternative products and similar are quite lower prices with robust results compare to all other disinfection solutions. UV protective hoods that allow people to work under UV radiation are quite lower cost for personal use, and much more effective to stop infection than various routine ways such as masks, protective clothes, and chemical sanitizers, etc.

This physical control method strongly recommended that from family items such as beds, masks, clothes, equipment, and rooms, etc., till all available public passages and assembly ranges such as retail stores, gyms, supermarket, hospital, cinema, libraries, meeting rooms, lecture halls, churches, flea markets, bank counters, custom passages, airports, commutation stations, and all manufacturing regions, etc., should be equipped with enough number of remote-controlled UV lights with administrations based on local potential risk levels. Remote-controlled is for avoiding direct shining on naked human skin and regulating with enough personal protections in severe contagious regions or selecting UV radiation box or similar devices while humans on-site for less critical areas. All UV lights should compose of explosion resistant safety glasses to comply with glass policy if affordable.

Historically, quarantine the contagious agents is the basic way to deal with all the infectious problems; masks, protective clothes, chemical sanitation, etc., composed of the quarantine system. This system deals with moderate infection quite effective; however, for stronger infection spreading with aerosol in public regions like what happened in China now, this system is insufficient. Now the recommended method doesn't quarantine the contagious agents, just make a partial or fully UV radiation active working environment; then, quarantine the UV hurt to naked skin and eyes instead of quarantine the infectious agents themselves. This method can effectively deal with the most severe biological infectious agent with low cost and impact on the human public life with minimum. We can see a concrete example to compare this UV quarantine method with the conventional quarantine equipped with masks, protective clothes, and chemical sanitizers. Suppose there is a $2 \times 2 \mathrm{~m}^{2}$ public area, with one health people and one infected people go in and out this region every minute in 8 hours period every day. If the health people use masks and protective clothes to prevent them from the infection, then some of the high impact masks or protective costumes need to resist $8 \times 60=480$ infected people's aerosol and other touched surfaces, any neglecting with the number of chemical sanitation round will induce a risk. Masks are useless while people are too close, even they can be disposable. Protective clothes are generally not disposable; however, the daily cleaning and changing of these protective clothes need complex equipment \& protocols that are generally challenging for those unprofessional people. Therefore, the use of protective clothing in the long term is also a risk. Applying chemical sanitizer for that region is also challenging; theoretically, each infected people go in and out 


\title{
International Journal of Science and Research (IJSR) \\ ISSN: 2319-7064
}

ResearchGate Impact Factor (2018): 0.28 | SJIF (2018): 7.426

that region needs one sanitation, that region needs 480 rounds of sanitation, lower than this sanitation number means a risk. Also, chemical sanitation only deals with contaminated surfaces, quite insufficient for aerosol contaminants in the air. From this case, we can easily see, for public regions with people continuously in and out, conventional quarantine is higher cost and yet quite reluctant to stop the infection. In contrast, a UV light in this region for 8 hours is enough to prevent all the infection under the same condition; also, quite cost-effective, just need some UV protection for each people in and out of that region. Compare to quarantine clothes, UV protection is a lower cost, easy to use for unprofessional people, and quite effective to stop the infection.

Conclusion, quarantine UV radiation personal impacts instead of quarantine infectious agents themselves is a lower cost and $100 \%$ infectious stop method under severe infection emergency conditions. UV radiation with personal protection can effectively replace routine precautions such as masks, protective clothes, chemical sanitation, quarantine hospitals, etc., under this urgent condition.

\section{Competing Financial Interests}

The authors declare no competing financial interests.

\section{Funding}

No funding.

\section{Author's Contributions}

Lai, Y.Y., perceived the models and wrote the brief.

\section{隔离紫外线本身代替隔离传染物是目前唯一已知 最有效的阻止2019-nCoV新冠状病毒在中国和}

\section{随后可能在世界其它地区迅速传播的有效物理控}

\section{制方法}

\author{
赖翠宇 $^{a b}$ \\ a清华大学医学院，医学科学楼B343，北京， 100084. \\ bInnoen 亿诺安非营利组织，加拿大，多伦多，L4Z 3E4，安省. yylai[at]innoen.org
}

\begin{abstract}
国际病毒分类委员会建议将当地称为 $2019-n C o V$ 的病毒 命名为SARS-CoV-2，全世界的实验室都在为治疗和解决 病毒传播问题尝试各种方法。免疫学疫苗的方法面临一些 挑战，因为这病毒的封套带有从寄主来的成分。更重要的 是，留给各种化学和生物学体系找到新药的时间所剩无几， 彻底斩断病毒传播是全球第一紧急优先考虑。在这种形势 下，使用紫外灯进行物理控制是目前已知有效用低成本阻 断传播的唯一技术方法。
\end{abstract}

紫外线是10-400nm的电磁波，比可见光波长短但是比X 射线长。阳光中也有 $10 \%$ 左右紫外线。人工装置中产生的 240-280nm波长的辐射通常用于空气，水和物品表层进 行脱污染或灭菌(DNA在260nm有吸收峰)。商业低压贡 灯可以产生高达 $86 \%$ 的 $254 \mathrm{~nm}$ 波长。这一产品和一些类 似产品，对比其它解决方法，都能低价位产生稳定效果。
当处于紫外灯下作业时候，紫外防护罩是比各种传统方法 如面罩, 防护服和化学消毒灯等更为廉价且更为有效阻挡 个人之间传染。

该物理方法强烈推荐，从家庭用品，例如床铺，面罩，防 护服等；直到各种公共通道和公共区域，例如，零售店， 健身房，超市，医院，电影院，图书馆，会议室，讲座厅， 教堂，跳虫市场，银行柜台，海关通道，机场，公交站和 各种企业生产区域等，应该装备足够数量的遥控紫外灯， 遥控是避免直接辐照到人体裸露皮肤。在严重疫情地区， 要求人们佩戴个人保护装置才能进入公共区域，而在疫情 不严重地区，可在人们离开公共区域后进行管理性紫外辐 照。当然，在能承受情况下所有紫外灯都应该使用防爆玻 璃，以符合玻璃易碎物管理政策。 


\section{International Journal of Science and Research (IJSR) \\ ISSN: 2319-7064}

ResearchGate Impact Factor (2018): 0.28 | SJIF (2018): 7.426

从历史上看，隔离传染物是对付传染问题的最基本方法， 面罩，防护服，化学消毒等等，都构成该隔离系统的组成 部分。这一体系对待中等烈度一下的生物传染病是有效的， 但是对于强烈传染病例如现在正在中国发生的可能涉及 气溶胶传染的新冠2019-nCoV是应付不暇的。现在建议的 方法不是隔离传染物，而是创造一个部分或全部紫外辐照 的工作环境，然后隔离紫外损伤而非隔离传染物，这种特 殊的隔离方法能够低成本有效对付最凶残的生物传染并 且对人们生活的冲击也降到最低。我们可以用一个具体实 例来比较一下紫外隔离和传统隔离使用的口罩, 防护服和 化学消毒。假设有一个 $2 \times 2 \mathrm{~m}^{2}$ 的公共区域，在 8 小时内 每一分钟都有一个传染者和一个健康人出入。如果健康人 使用口罩或者防护服，那么某些口罩和防护服需要抵挡8 $\times 60=480$ 个传染者的气溶胶及接触表面，在这整个过程 中任何疏忽都是风险。另外，即使是一次性口罩，在近距 离使用时也几乎无用。目前的防护服不是一次性使用，其 清洗需要很复杂口罩实际的设备和程序，对没有受训的非 专业人士是很大挑战。长期使用防护服本身就是风险。使
用化学消毒也是挑战。理论上，刚才所述那个公共区域每 个传染者进去都应该进行化学消毒，那就是那个区域每天 需要480次化学消毒，低于这个消毒次数都是风险。另外， 化学消毒通常只能对付器物表面，很难对付空气中的气溶 胶携带传染物。从这个案例我们可以看到，对于有人员不 停出入的公共区域，传统隔离不仅成本高而且要阻断传染 非常勉强。但是该区域如果有一盏紫外灯进行8小时紫外 辐照，足以低费效比的阻断任何传染，只是进入该区人员 需要一些个人使用的紫外防护。对比病毒隔离防护服，个 人紫外防护不仅价格低，易于被非专业人士使用，而且能 有效阻断传染。

结论，在紫外工作区隔离紫外伤害代替隔离传染物本身的 方法是一种在严重疫情区低成本100\%有效斩断传染的 方法。这一方法在特殊状况下应用能够低成本有效代替传 统的面罩，防护服，化学消毒和隔离等传统隔离传染物的 措施。

To understand the simple method in the paper, we demonstrate examples of UV quarantine in a company, a family, and how to use UV hoods or similar as an ultimate method in public regions, detail in (Fig. 1-3). These figures are the supplementary info of the paper after the Chinese interpretation section of the paper.
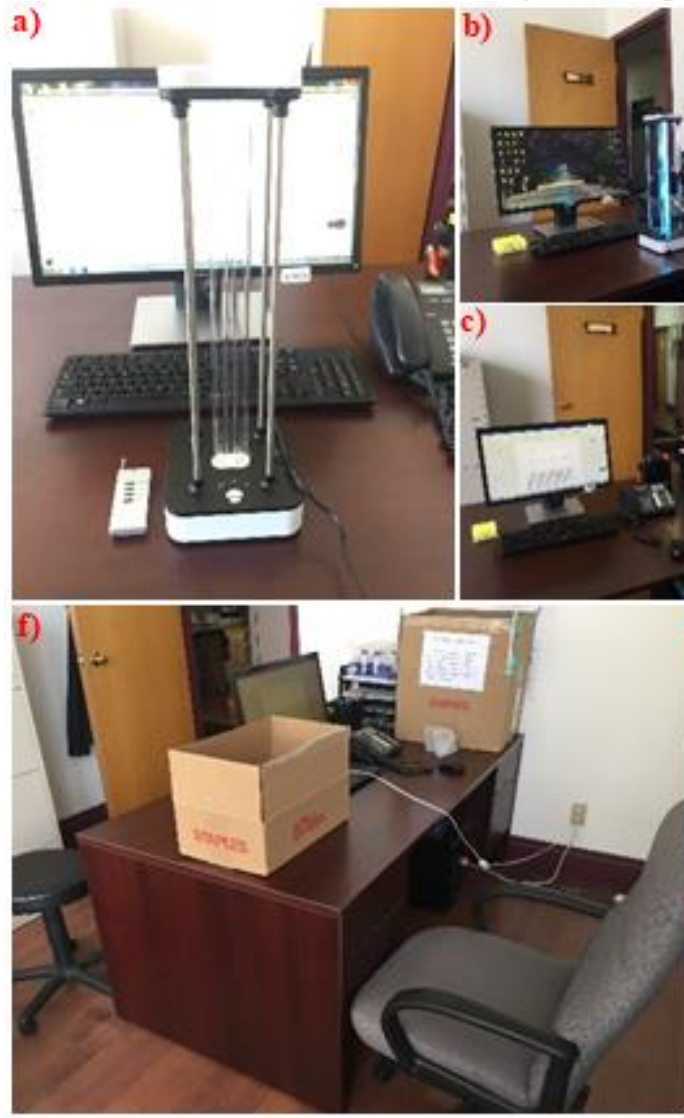

Fig. 1 | UV quarantine method applied in a company
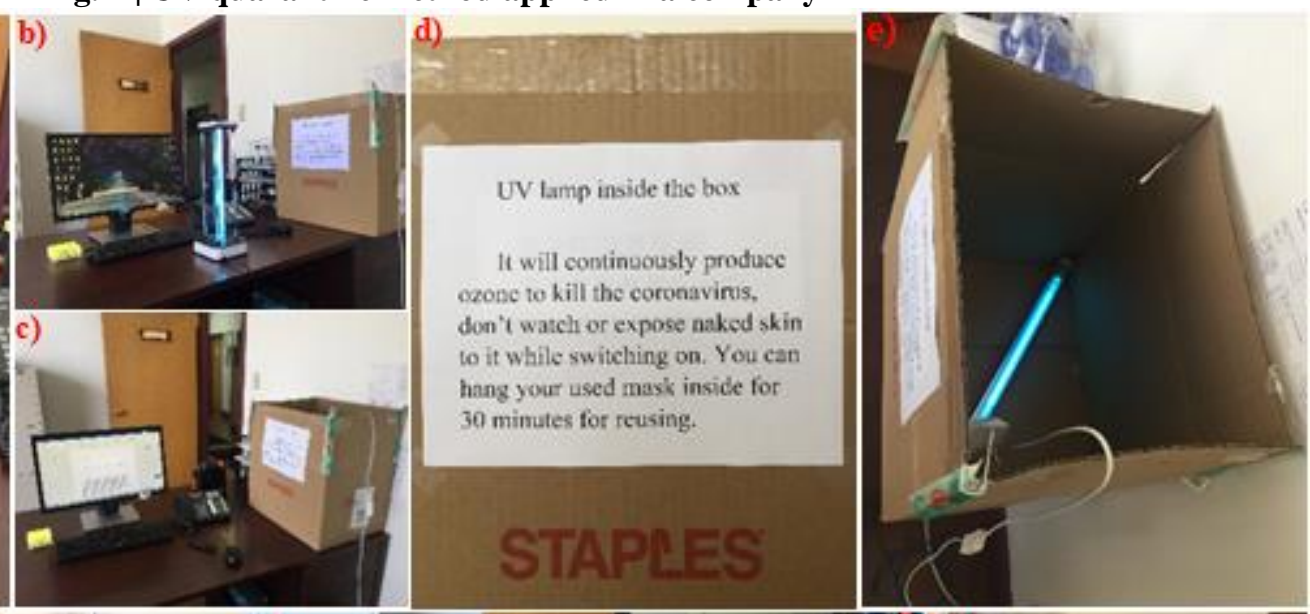

g)
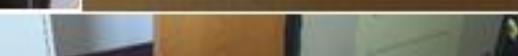

Pr:

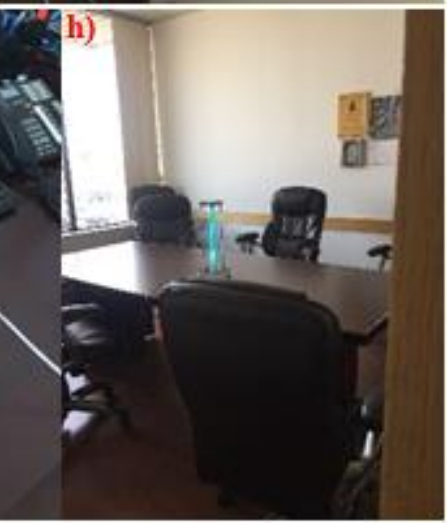




\section{International Journal of Science and Research (IJSR) \\ ISSN: 2319-7064}

ResearchGate Impact Factor (2018): 0.28 | SJIF (2018): 7.426
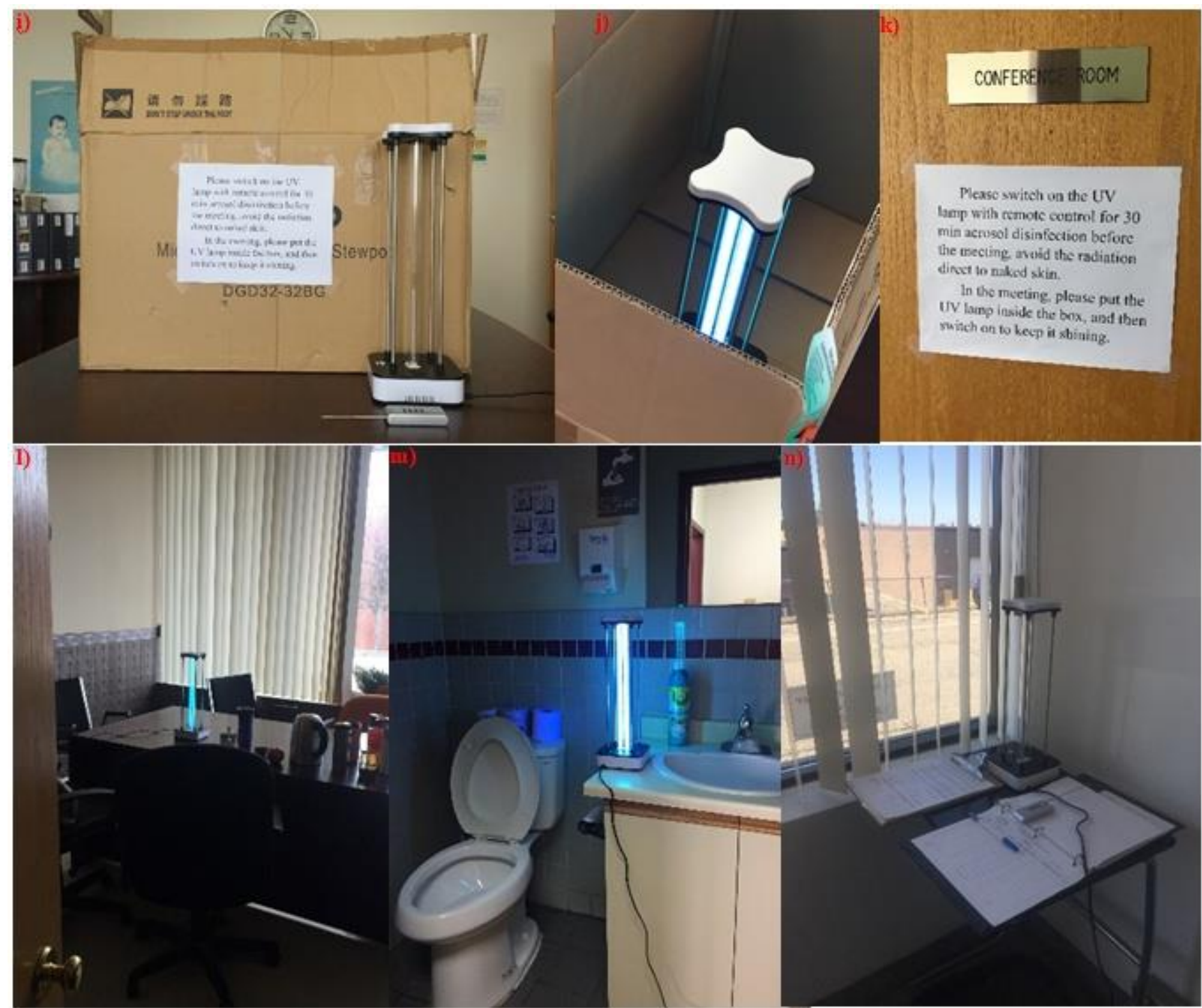

a) a UV lamp with remote control on my office table, its remote control has 15 seconds of lag time with beeps, which helps people to avoid directly radiating on naked skin. b) before entering into the office room, I light up the UV lamp for $30 \mathrm{~min}$. c) after 30min of mandatory UV disinfection for the table, then I can work. You can see a cardboard box nearby the computer. We call such kind of box as "UV radiation box", it can be conveniently made from various available ways. d) the post on the UV radiation box. e) the UV lamps continuously shining inside the UV radiation box while I'm working, due to the cardboard box, working on the computer is safe, no UV radiation directly on naked skins, and the ozone produced by the UV lamp permeating the room to kill the coronavirus. f) this is a small "UV radiation wall" box, while I need to talk with some people, we sit on the chairs in the photo and put such a cardboard box between us, no masks required. We must carefully note, masks no matter what types and how to use, can't filter viruses. They can only reduce the concentration of aerosol virus invading into the sacrificed human respiratory system. Suppose in a certain environment one deep breath will inhale X concentration of aerosol coronavirus without a mask, then under the same condition, inhaled coronavirus concentration with masks can be reduced to around 0.3-0.6X. Because masks only can reduce the concentration of inhaled viruses and can never eliminate them, it is still dangerous for people with masks to close to each other. While two people approach to a certain distance, masks become useless for protecting them from infection. For this reason, a UV radiation box is quite effective than those of masks in a room. As mentioned, masks can only reduce the inhaled virus concentration to $0.3-0.6 \mathrm{X}$; a UV radiation box under the same condition can easily reduce the inhaled virus concentration below $0.001 X$. Therefore, in our conference room and dining room, the UV radiation box has totally replaced the use of masks. While using the $\mathbf{U V}$ radiation box, there is a slight ozone smell in the air; however, it is still much more acceptable than masks in a meeting room. This way can be done most static indoor places in the world. g) now, you can see the UV lamps shining inside the cardboard box, it produces an invisible UV radiation wall to kill the virus. This UV radiation wall does not directly shine on naked human skins and with a virus clean efficiency even better than that of a UV radiation box in (Fig.1b). Under such a situation, the aerosol coronaviruses between are 100\% be stopped to infection; it is a device offering safe talk between healthy people and a heavily infected person. h) our conference room, before entering there, we light up the UV lamps for $30 \mathrm{~min}$. After 30min of mandatory UV shining to clean the virus in the air, we then can go to the room to start a meeting. i) if there are some people doubt of infection, we use such a UV radiation box. You can see the post on the box "Please switch on the UV lamp with remote control for 30 min aerosol disinfection before the 


\section{International Journal of Science and Research (IJSR) \\ ISSN: 2319-7064}

ResearchGate Impact Factor (2018): 0.28 | SJIF (2018): 7.426

meeting, avoid the radiation direct to naked skin. In the meeting, please put the UV lamp inside the box, and then switch on to keep it shining". j) the UV lamp is continuously shining inside the UV radiation box while we are meeting; we are safe due to the box can quarantine UV hurt, and also the ozone produced by the UV lamp can kill the virus in the air. k) the post on the company conference room gate, same with that on the UV radiation box. 1) company dining room is taking a 30 min mandatory UV shining before lunch, this process can offer a room 100\% free of coronavirus aerosol for dining, same with that in the conference room, we put a UV radiation box with a UV lamp shining inside while eating. m) one of the company washrooms, we mandatorily require every washroom must take $30 \mathrm{~min}$ UV disinfection before use. In the photo shows a single space washroom, for a multi-space washroom, UV lamps put in each space for 30min before each use. And a multi-space washroom also needs a UV radiation box in each space if we want to minimize the risk. Note: The public washroom is a critical infection transmission site, and the only feasible and quick sanitation method is still by means of a UV lamp before each use. Chemical sanitation is impossible to do before every use, and also quite weak for aerosol disinfection. n) the company registration, we still put a remote-control UV lamp on the registration desk. Before people come in and leave the door, we follow up with a 30 min UV disinfection. This is a critical step to prevent the virus from accumulating in the entrance door region.

For the company area, the principle is the same, for everything takes a 30 min UV disinfection before use. And put a UV radiation box (wall) if it is shared by more than one person. This rule comes from laboratories; biosafety cabinets, bio-clean rooms, pharmaceutical clean rooms, etc., are routinely taken 30 min UV disinfection for the air disinfection before each use. Now we just extend the biological laboratory method to the companies and families. For the UV radiation box (wall) method described in (Fig.1), that is to increase the ozone in the room for people not confirmed of coronavirus infection, and also need to use that pubic region. This way can minimize the required "Social distancing". To date, there is indeed no empirical evidence for the officially regulated "Social distancing". However, the method of increasing the ozone in the region to inhibit infection agents has stronger empirical evidence and a long history of board applications; all the biological laboratories in the world have relied on UV lamps for air disinfection.

Inside a family, we still use the same principle; issue 30 min UV disinfection for any rooms, equipment, utensil, etc. For more than one people share one room, one table, one piano, one gym region, one toy room, etc., then need to use a UV radiation box or similar device to replace masks, as shown in the company administration of (Fig.1). If any company or family member gets confirm of coronavirus infection, then all members have to use UV hoods, which we'll refer to in (Fig.3).

In (Fig.1) of company demonstration, we don't refer to the ventilation system, since most of the air inlets are on the roofs and inaccessible to people, for a family, or public apartments (condos) with central air-conditioning, need to consider the safety of air ventilation as a media for coronavirus transmission first. Now we can see an example of a family UV quarantine.

Fig. 2 | UV quarantine method applied in a family
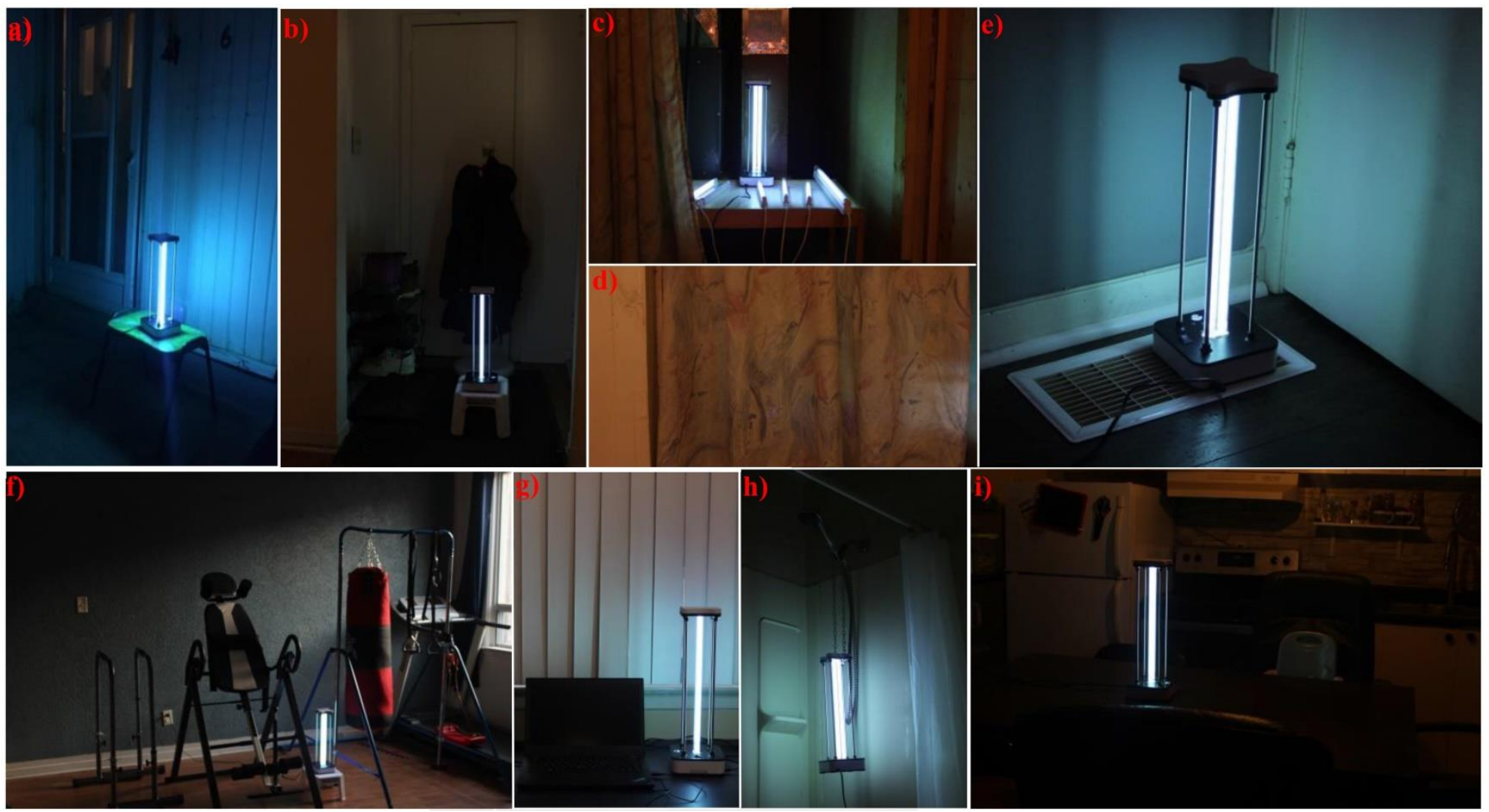

Volume 9 Issue 3, March 2020 


\section{International Journal of Science and Research (IJSR) \\ ISSN: 2319-7064}

ResearchGate Impact Factor (2018): 0.28 | SJIF (2018): 7.426

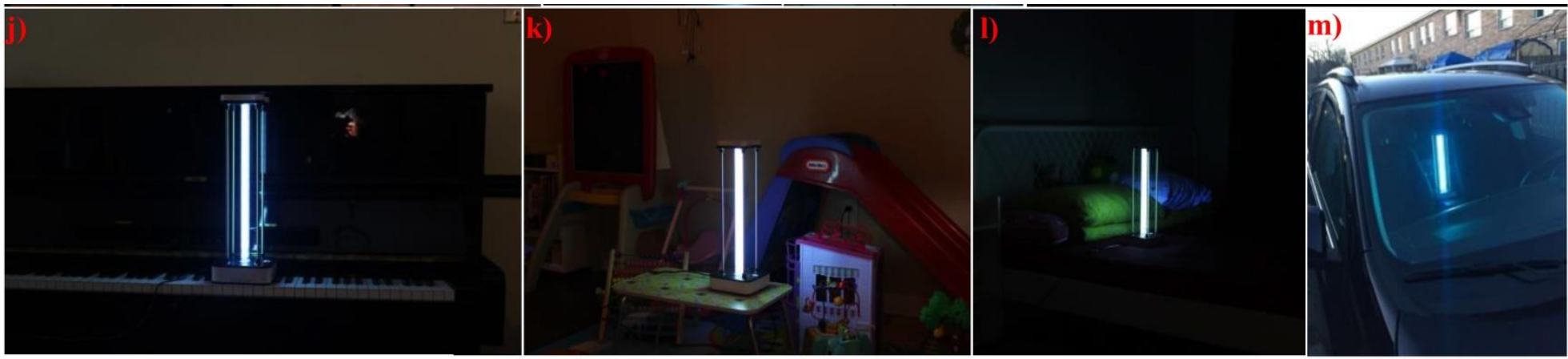

a) the family entrance door (outside), use a UV lamp to clean the outside entrance door is easy, just after every member back to the home, arrange a 30 min UV shining; this is important to prevent the accumulation of coronavirus in the region. b) the family entrance corridor (inside), in here, outside shoes, clothes are taking a $30 \mathrm{~min}$ UV disinfection after everyone back home. For houses without such a corridor, it is still critical to use a UV lamp in the same way. c) UV lamps in the basement, near the ventilation air inlet, we can see there are eight UV lamps with different sizes present there. The calculation of the numbers of UV lamps in this region is based on the product instruction that an $8 \mathrm{~W}$ UV disinfection lamp can cover $12 \mathrm{~m}^{2}$ static area. Due to the air from the air-condition ventilation need send to all rooms, the number of UV lamps here should enough to cover the total area of all rooms of the house and not just the basement. Such an air inlet UV control method is relatively simple; then there is no need to take care of every air outlet in each room. d) the basement UV lamps use such a curtain to prevent the UV radiation directly shine on the people walk around, also prevent kids from accessing this region. e) this is a room ventilation outlet. If we lack control of the ventilation air inlet by UV lamps, then every ventilation outlet needs such a UV lamp, and also a cardboard box or similar device needs to shield the UV lamp from hurt people walk around. In an apartment or condo, control of the ventilation system is critical, since all the rooms share a central air conditioning, and the air inlets of which general not like those in a supermarket or manufactory site to be installed on the roof, infected people possibly access them. Therefore, in an apartment or condo, it is critical to use UV lamps at each ventilation outlets like this figure and also need to shield them. Ventilation control by UV quarantine should be $24 / 7$, not something with only $30 \mathrm{~min}$ UV shining before each use if unknown of the air inlet control conditions. f) the family gym is taking a 30 min UV disinfection before each use. g) the family study table is taking a 30 min UV disinfection before each use. h) the family shower \& washroom is taking a $30 \mathrm{~min}$ UV disinfection before each use. i) the family kitchen \& dinar table is taking a 30 min UV disinfection before each use. j) the family piano is taking a 30 min UV disinfection before each use. $\mathrm{k}$ ) the family kids' room is taking a 30 min UV disinfection before each use. 1) the bed is taking a 30 min UV disinfection before each use. $\mathrm{m}$ ) the car is taking a $30 \mathrm{~min}$ UV disinfection before each use. Note, for a family car, even it is only used by one person, arrange routine $30 \mathrm{~min}$ UV disinfection is still necessary. A virus infection needs to trigger at a certain concentration threshold. If a person goes to work every day and always contacts with the virus at a lower than infection threshold, the virus concentration possibly accumulates inside his car to attains the threshold in a long period. UV disinfection in such a way can stop the virus accumulation process of the car.

From (Fig.2f-m), each region, each stuff, etc., still takes the same principle, a 30 min UV disinfection before each use, while only one person uses them. If two or more people share one room, one piano, one study table, one dinner table, one toy room, one gym device, etc., a UV radiation box is quite necessary. For kids' room, if more than one child in there, we still need to put the UV radiation box on-site, and then need a baby sitter to prevent the children from dumping or damaging the box and leak the UV shine to hurt the naked skin. In a family, follow the abovementioned principle is vital, especially some people confirmed of infection and need to "quarantine at home", the only way to quarantine at home is still using UV quarantine method and strictly follow the above principles. Even for a school, a public library, etc., if the virus is not severe, we still can use the same way, such as 30 min UV shining for the classroom, then on each children's table put a UV radiation box. On a bus, an airplane, a restaurant, etc., 30min UV disinfection plus enough shielded UV radiation boxes to issue ozone, can greatly inhibit the coronavirus infection. Especially in a quarantine hospital, it is truly important to control the ventilation system, and also the rooms quite need the above UV quarantine method. However, for public regions with more people come in and out with a higher frequency, such as customs, airplanes, cinema, large slaughtering houses, etc., or for severely infected districts even without so dense visits, the above method becomes insufficient. We then have to light up enough UV lamps in these public regions and require everyone to go into the region with personal UV protection, such as a UV hood, and a pair of gloves, etc. We call this way as a UV hood method or the ultimate UV quarantine method. Now we can see what a UV hood is. They are just some simple human portable UV protection to be used in UV lamp active public regions.

\section{Fig. 3 | Ultimate UV quarantine method with UV hood in UV lamp active public regions}

a) Some types of commercial products which could be directly used as a UV hood for the UV quarantine method
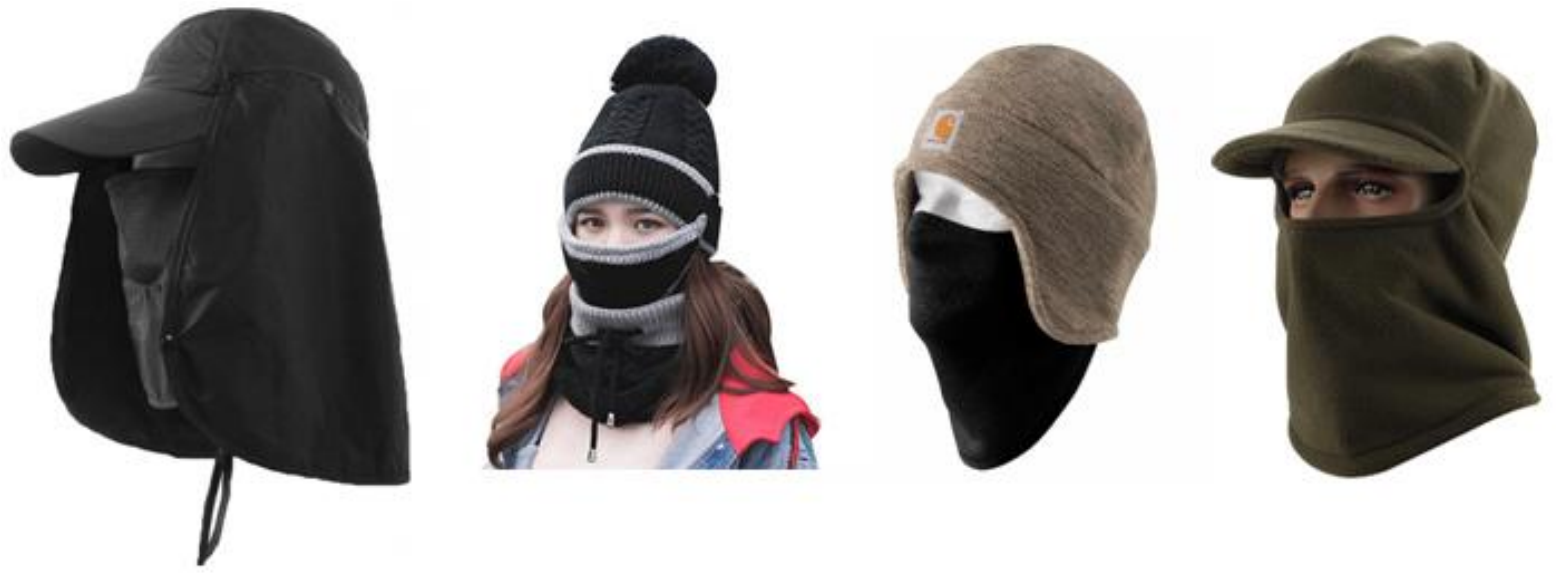

Volume 9 Issue 3, March 2020 www.ijsr.net 


\section{International Journal of Science and Research (IJSR) \\ ISSN: 2319-7064}

ResearchGate Impact Factor (2018): 0.28 | SJIF (2018): 7.426

b) Some types of commercial products claimed of UV protection functions; however, they only can shut off the natural UV radiation in the sunlight, can't be used for our UV quarantine method under stronger artificial disinfection UV lamps.

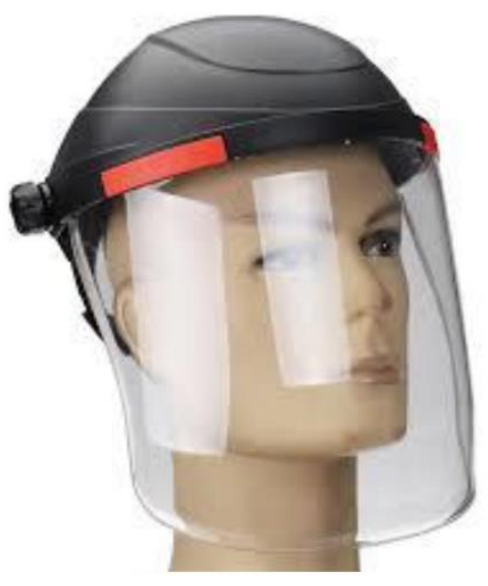

c) This type of goggles can be used for UV quarantine

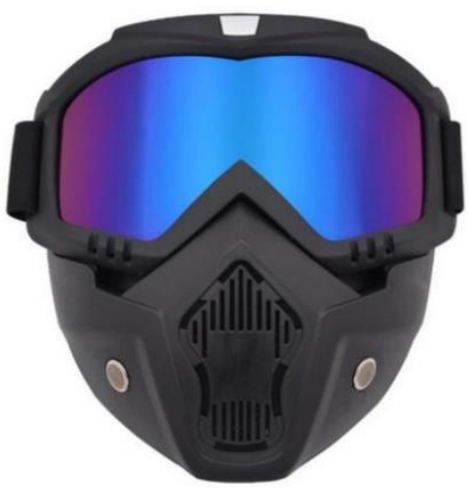

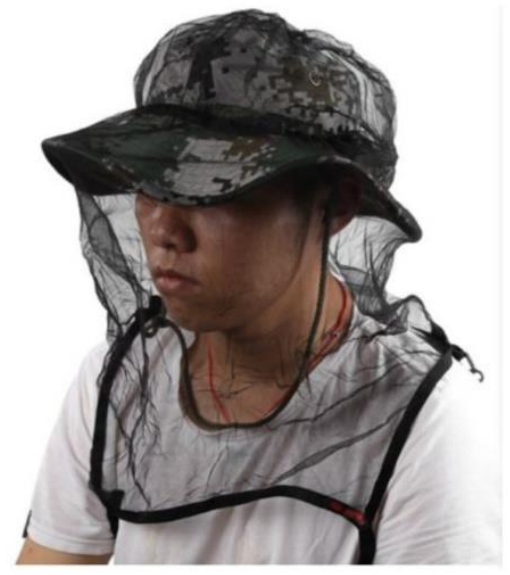

d) even a common umbrella can be used for UV quarantine

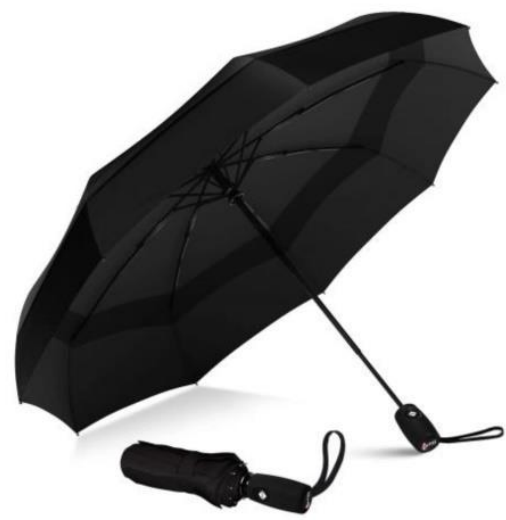

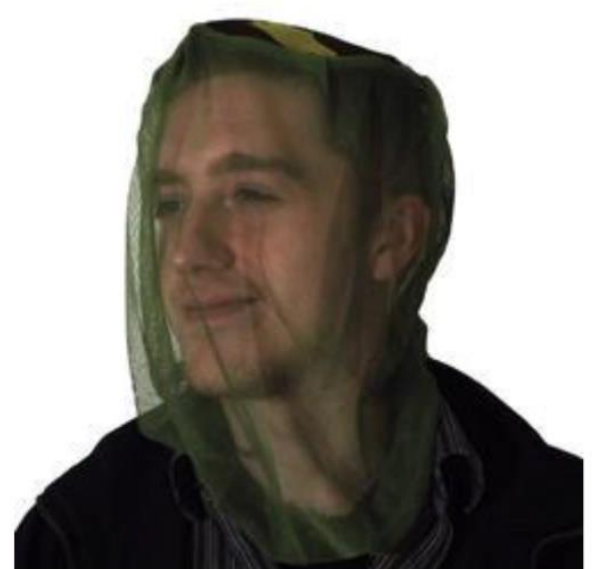

e) These types of products are not safe, need further UV quarantine

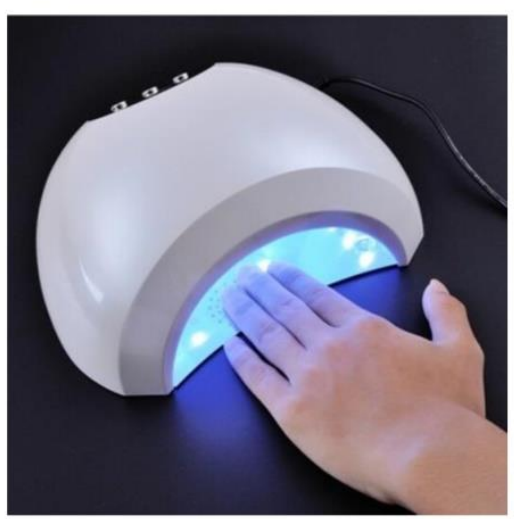

It is anything with one layer of cloth or similar to protect the naked skin, not necessarily the same with those in the (Fig. 3a). People can self-make one or just purchase an equivalent from the market. Note, they are not used to "filter" the coronavirus passively. UV-shine in the air already has 100\% stopped all the aerosol transmission between people; the UV hoods only protect the UV hurt on naked skins of people. They can be dealing with as an ordinary cloth, throw into a washing machine if dirty, no need for any specialized sanitation, UV radiation is a good physical "sanitizer" for them. It is even no need for nucleotide or even temperature measurement while applying UV quarantine since UV light can $100 \%$ cut off the infection; just need people to use simple personal UV protection. For a community, yet with $80 \%$ of the population get infected, the UV quarantine method with UV hoods still can protect the remaining $20 \%$ of people free from the infection. UV hood is the ultimate choice for stopping the COVID-19 or other biological infectious agents.

For some commercial products like those in (Fig. 3b), they are designed for shut off UV radiation in natural sunlight, can't be used for our UV quarantine method with stronger artificial disinfection UV lamp source. The product in (Fig. 3c) can be used for the UV quarantine method, a little bit expensive. The goggles for welders or the helmet for astronauts still work well. However, generally, it is no need for such kinds of goggles; just simple things like those in (Fig.3a) can effectively prevent UV hurt in public regions if people are careful. Under some condition, even a dark-colored common umbrella as that in (Fig.3d) works quite well as a temporary UV hood. Suppose a supermarket or a Border Custom passage lights up enough numbers of UV lamps on the ceilings and require all the people to use personal UV hoods before entering. Some people forget to bring their personal UV protection, then just offer them dark-colored common umbrellas for temporary use in that public region for avoiding UV hurt, which still works quite well. We also need to note, some fungi killing products that well available in the market like that in (Fig.3e) are not safe. If we want to use these types of products for fungi foot or fungi nails, we need to cover the naked skin and only allow the nails to get UV radiation. Simply use a pair of thick gloves, cut holes in the nail regions, then can use them. These types of products are much more effective than chemical medicine for fungi foot (nails); however, no such instructions on the product brochures; therefore, a reminder here albeit they are not directly concerned with COVID-19; just cutting holes on gloves is still a standard UV quarantine method. 


\section{International Journal of Science and Research (IJSR) \\ ISSN: 2319-7064}

ResearchGate Impact Factor (2018): 0.28 | SJIF (2018): 7.426

Right now, it is really no better solution worldwide. For those who interested in developing a drug, a vaccine, or a test method, they should be very careful not to get infected before they work out a drug or a vaccine, then the method writes in the paper becomes the only solution. Also, most people get confirmation of coronavirus infection without severe symptoms are encouraged "to quarantine at home". So-called "quarantine at home" has to "quarantine the UV hurt" instead of quarantine the infectious agent and shine the UV light everywhere at home and follow what demonstrated in (Fig.2). Diverse hospitals easily become secondary infectious sources if they fail to use the UV quarantine method carefully. Most important, asymptomatic coronavirus patients have emerged everywhere in the world. For the asymptomatic coronavirus patient crisis, our ultimate UV quarantine method is the only known effective solution. No alternative way can be available! Never trust the so-called "mass immunization", human gene mutation rate only $10^{-9}$, even if we suppose an inflated population mutation rate of $10^{-6}$ for human species, that means one million people sacrificed by different degrees of hurt, and finally only one person gets a positive mutation. Following this data, for a nation like Canada with around 30 million population, finally, only 30 people get positive mutations, for the USA with around 300 million population, finally, only 300 people get positive mutations; even for China with the largest population in the world, only around 1500 people can finally get positive mutations, all the remaining people have to be suffered by diverse ways, such as death, organ failure, loss of hearing or smell, immune system weakening, activation of hidden medical problems, enhanced senility, etc. I don't think this terrible result for the human race on Earth is what those politicians really want while they made speeches for the "mass immunization" pretexts.

Emergent Law should mandatorily require that all public regions equipped with enough UV lamps for people to use them under infection emergency conditions. It's feasible, cost-effective, irreplaceable, and 100\% stop the infection, including the infections induced by the asymptomatic COVID-19 patient.

\section{文章附件信息的中文翻译:}

为更好理解和贯彻实行UV隔离, 我们用3幅图(Fig. 1-3) 详细介绍一家公司,一个家庭, 以及怎样在大多数公共场所使用UV隔离作为 终极手段去对付病毒传染. 这些图是文章中文翻译之后的附件部分:

\section{Fig. 1 | 紫外隔离在一家公司中的使用案例}

a )在办公桌上的一个遥控紫外灯，其遥控有15秒延迟，防止人们不小心照到裸露皮肤上.另外有金属框能在一定程度上防止摔坏. b) 进办公司以前先进行 30 分钟紫外辐照. c ) 完成 30 分钟紫外杀菌后，可以开始工作，您可以看到电脑旁边一个纸盒子，我们称其为"紫外辐射盒"，可以用多种材料多种方式简单制成. d ) 这是"紫外辐射盒"上面贴的告示. e ) 当人们 在电脑上工作时候, "紫外辐射盒"里面的紫外灯继续工作,因为纸盒子遮盖作用,在旁边电脑上工作是安全的,紫外灯并没有照到裸露皮肤砂锅内,同时紫外灯产生的臭氧弥漫整个房间 杀死新冠状病毒. f) 这是"紫外光墙",需要谈话的两个人坐在图中两个椅子上, 不必带口罩. 我们需要明白, 一般使用的口罩, 只能降低进入肺中病毒浓度,完全不能杀死所有病毒.假设 在一个某种环境中不戴一次深呼吸所吸入的病毒浓度为X,同样情况下戴口罩只能把病毒浓度降低到0.3-0.6X. 因为口罩只有这点作用，所以人们即使戴口罩离得太紧仍然是危险的。 只要近到一定距离, 口罩完全没有作用.我们所用的紫外辐射盒完全不同于口罩,在同等情况下可以轻易把吸入病毒浓度降低到 $0.01 X 以 下$. 所以在我们会议室和餐厅, 紫外辐射盒已 经完全代替口罩. 当使用紫外辐射盒时候, 空气中会有轻微臭氧味道,但是至少比戴口罩开会更容易让人接受. 这种方法完全可以在全世界大多数室内静态环境使用. g ) 现在您可以 看到,紫外光墙里面的紫外灯在继续发光.这个看不见的紫外光墙并没有紫外光直接照射到裸露皮肤上,但是有比紫外辐射盒(Fig.1b)更为强大的病毒阻杀作用.在这种情况下,两人 之间的病毒气溶胶可以 $100 \%$ 失去传染作用.这是一种健康人和重症病人之间进行安全谈话的保障装置. h) 会议室,在进入开会前,进行 30 分钟紫外杀菌,只有符合规定的 30 分钟辐 照,才能进入开会. i ) 如果怀疑开会人员中有轻微感染, 我们使用这个紫外辐射盒. 您可以看到盒上的张贴:"请在开会前用遥控打开紫外灯进行 30 分钟辐照,避免紫外光直接接触裸 露皮肤.在开会过程中请把紫外灯放入盒子, 然后开会时紫外灯在盒中继续点亮". j) 紫外灯在紫外辐射盒中继续点亮. 因为盒子所有与会人员是安全的,同时紫外灯产生的臭氧能够 杀灭空气中病毒．k ) 这是公司会议室门上的张贴,内容与会议室内紫外辐射盒上相同．1）公司餐厅正在进行进餐前 30 分钟紫外辐照,这样能提供 $100 \%$ 没有病毒气溶胶的餐厅空 间，然后进餐过程中同上使用紫外辐射盒. m) 这是公司的一间则所正在进行紫外辐照，这个照片中是一个单间则所，如果有多个隔间的则所，则在隔间内部进行紫外辐照.如果为降低 风险,多个隔间的刚所里也应该使用紫外辐射盒. 注意: 公共则所是一个比较容易传染的地方，唯一能够使用的杀菌方法仍然是紫外灯，化学消毒不可能在每个人使用前和使用中进行， 而且用化学消毒来对付气溶胶非常不给力. n) 公司入门登记处, 我们放上一个遥控紫外灯，每个到访人员离开后，都进行紫外辐照，这是防止入门处病毒积累的关键控制点.

在公司范围内,原则其实是相同的. 对每样东西都是使用前进行30分钟紫外辐照,如果某种东西被超过一个人共同使用,则加上紫外辐 射盒或紫外光墙. 这个原则其实来源于生物实验室;超净工作台,无菌室,制药厂洁净室, 都是使用前进行30分钟紫外辐照以清除空气 中微生物.我们现在只是把实验室方式搬到公司和或家庭. 对于(Fig.1)中的紫外辐射盒或者紫外光墙,目的是提高臭氧浓度阻止病毒 在非确诊人员中传染. 这种方法能大大降低所谓"社交距离".实际上,到今天为止,社交距离并没有多少实验依据.相反,紫外线杀菌已 经有非常长远的历史和广泛应用, 全世界所有生物实验室必须依赖紫外灯今昔空气灭菌.

在家庭内部, 也是使用同样原则. 对于各种房间,物品进行 30 分钟紫外辐照, 然后超过一个人共享一个房间, 一个桌子, 一架钢琴,一套体 育训练设备,一个玩具房等等,都安上一个紫外辐射盒或类似装置去代替口罩,如(Fig.1)中显示的那样.如果公司或家庭成员确诊新冠, 则必须使用紫外防护用具开灯作业, 这就是紫外隔离终极方法,我们会在 (Fig.3)详述.

在(Fig.1)中公司措施部分,我们没有涉及通风系统,因为大多数公司通风系统进气口在屋顶,一般人无法接近.但是对于家庭,或者公寓 一类使用中央空调的房屋结构,必须考虑通风系统造成的病毒传染. 现在我们来看家庭如何进行紫外隔离.

Volume 9 Issue 3, March 2020 www.ijsr.net 


\section{International Journal of Science and Research (IJSR) \\ ISSN: 2319-7064}

ResearchGate Impact Factor (2018): 0.28 | SJIF (2018): 7.426

\section{Fig. 2 |紫外隔离在一个家庭中的使用案例}

a) 在家门外面使用紫外灯, 通常每个家庭成员回家后进行 30分钟辐照,这是防止病毒在这一区域积累的关键.操作比较容易. b ) 家庭内部门庭,在这里室外用鞋和衣物进行 30分钟 辐照.对于没有这种内部门厅的房子,可以用同样方法对室外用鞋和衣物进行清毒. c ) 家庭地下室空调入口处,我们可以看到有八盏各种不同大小的紫外灯,在这一区域中紫外灯使 用数量是根据厂家提供的每 $8 \mathrm{~W}$ 能对 12 平方米静态房间进行杀菌的参数计算的. 因为空调需要把空气输入每一个房间, 所以这里必须把房子所有房间面积加起来进行计算. 这样安排 比较容易，因为不必再单独考虑每个房间的通风口. d) 地下室空调空气入口处的紫外灯用这样一块窝子遮挡，防止人员在附近活动时候直接照到裸露皮肤上，同时严禁小孩进入这一 区域. e ） 这是一个房间的出风口，如果没有对进气口进行控制，那么每一个出风口都必须控制，而且出风口的紫外灯必须用紫外辐射纸盒或则类似装置防止附近活动的人员裸露皮 肤被照到．在使用中央空调的大型公寓内，通风系统的控制必须严格把关，因为这些公寓不想超市或则厂房,通风系统入口安在高处人员不易接近地方，通风系统的控制必须7天 24 小 时，不像其它地方只进行 30 分钟辐照.特别是不清楚入口处控制的情况下.f)家庭体操房正进行 30分钟紫外辐照.g)家庭书房正进行 30 分钟紫外辐照. h) 家庭浴室正进行 30 分钟紫外 辐照. i) 家庭厨房和餐桌正进行 30 分钟紫外辐照. j) 家庭钢琴正进行 30 分钟紫外辐照. $k$ ) 家庭儿童玩具房正进行 30 分钟紫外辐照. I) 家庭卧室床铺正进行 30 分钟紫外辐照. m) 家庭用 车正进行 30 分钟紫外辐照. 必须注意: 即使某一辆车只被一个家庭成员单独使用,还是必须经常进行这样的辐照.病毒感染需要一个浓度域值.如果一个人每天出去工作, 接触到的都是 低于域值的病毒浓度,但是一定时间间隔下有可能在他单独使用的车里积累到感染域值浓度的病毒量.现在进行这种紫外辐照可以彻底打断病毒在车里的积累过程.

从(Fig.2f-m), 每个区域物品,都是相同原则,使用前30分钟紫外辐照,共用时候使用紫外辐射盒. 对于孩子玩具房,如果两个或多个孩子 共同使用,仍然需要使用紫外辐射盒,但是需要人员照看,防止孩子不小心弄坏或弄翻紫外辐射盒而让紫外线直接照到裸露皮肤上. 对 于家庭,按照上述原则是非常重要的,特别是有家庭成员轻症感染需要在家隔离.对于学校,图书馆等等,如果属于非重疫区,也可以用 这种方法.上课前 30 分钟辐照教室,然后每个小孩桌上放紫外辐射盒.公交车,飞机上,30分钟辐照加上紫外辐照盒是非常必要的.特别 是在医院,非常需要控制通风系统,然后医生和护士办公室也需要上述紫外控制方法.但是,对于某些公共场合,人员出入频率非常高, 或者虽然人员出入频率不是非常高,但是属于重灾区,例如:海关,机场,电影院,人员多的生产区域,上述紫外辐射盒的方法还不够,我们 就需要在这些地方点亮紫外灯,开灯作业,然后要求每个进入该区域的人员使用紫外防护用具.我们把这种方法叫紫外隔离终极方法. 现在我们可以看看什么是紫外防护用具.

一般单层布防止紫外线照到裸露皮肤上就能成为紫外防护用具,不一定完全是 $(\mathbf{F i g . 3 a})$ 中形态.人们可以自制或则从市场上买到类似 产品.注意,这些东西不是用于被动"过滤"冠状病毒.空气中紫外线已经 $100 \%$ 阻杀了气溶胶中病毒在人群中传播,这些紫外防护用具只 是防止紫外线对裸露皮肤的伤害.这些用具脏了可以直接像衣物一样丢入洗衣机,不需要特殊消毒,紫外线就是好的消毒剂.使用这种 方法,可以不需要核酸检测, 因为紫外线已经杜绝拉传染.在人群中即使 $80 \%$ 的人感染了病毒,这种方法也能保证剩下的 $20 \%$ 不被感染. 紫外防护用具是对COVID-19或则其它生物传染的终极选择.

\section{Fig. 3 |在公共场合开灯作业所使用的紫外隔离终极方法}

a) 一些商业产品可以直接用来进行紫外隔离. b) 这些产品说明书上是可以作为紫外防护用具,但是它们实际是为防护自然阳光中紫外线,无法在强的人工紫外灯下进行紫外隔离. c) 这种护目镜可以用于紫外隔离. d) 某些情况下, 即使一个普通深色雨伞也可以用于紫外隔离. e) 这种产品并不安全.需要进行进一步的紫外隔离.

对于某些类似(Fig.3b)的商业品, 是防止自然光线中紫外线, 无法用于紫外隔离, 对于某些类似(Fig.3c)的商业产品可以用于紫外隔 离，只是有些价格昂贵.电焊工和宇航员的护目镜也可以等同使用,不过一般情况下没有必要,使用类似(Fig.3a)的产品只要小心就足 够防止紫外伤害,某些情况下甚至一把深色的普通雨伞(Fig.3d)也可以用于紫外隔离。例如一个超级市场或则海关通道在天花板上点 亮啦足够数量紫外灯, 并要求进入这一公共区域的人员带个人紫外防护用具, 但是一些人忘记携带, 于是可以提供一些普遍深色 雨伞给他们暂时使用, 仍然可以起到很好的防护作用. 另外我们需要注意, 一些香港脚或真菌指甲产品在市场上很常见(Fig.3e), 但 并不安全.如果我们要用这类产品, 必须覆盖裸露皮肤。例如戴一副厚手套, 在指甲盖地方剪开洞, 这样就可以使用了. 这些产品 对付真菌指甲或香港脚比化学药品更为有效, 但是没有见到任何一种产品的说明书上写出这种隔离用法, 所以在这里提醒, 这些 产品与 COVID-19 直接关系不大, 但是从方法学上来说, 在手套剪洞就是一种标准的紫外隔离方法。

现在世界各地并没有更好的对付新冠的方法.对于那些希望研发药物, 疫苗和检测方法的科学家,需要注意不要在产品出来前就被感 染.另外,大多数轻症病人被要求 “家里隔离”,所谓家中隔离, 还是必须依赖紫外隔离而非隔离传染物.各种类型的医院,如果不进行 紫外隔离会非常容易成为二次传染源. 更为重要的是,世界各地都出现无症状传染者,对于无症状传染者危机,唯一方法只是紫外隔离, 而没有其它任何替代性选择. 不要相信所谓群体免疫,人的基因突变率 $10^{-9}$,即使我们按照 $10^{-6}$ 突变率计算,也就是一百万人中一个正向 突变.那么,像加拿大这种三千万人口的国家,最后只有 30 个人得到正向突变,美国大约 3 亿人,只能得到 300 个人正向突变,即使是人口 最多的中国，大约只有 1500 人得到正向突变.剩下的人，必定受到各种不同程度的伤害，例如:死亡，器官衰竭，失去听力，免疫系 统弱化, 并发症诱导, 加速衰老, 等等多种结果. 恐怕那些政治家在进行所谓 “群体免疫” 演说时候, 也不希望这种对人类这个物 种的可怕场面出现吧?

必须颁布紧急状态法要求所有公共场所装备足够紫外灯,以供人们在紧急状态下使用.这种方法可 行, 费效比高, 难替代, $100 \%$ 阻断传染, 包括那些无症状传染者引起的传染. 